\title{
Water Footprint and Virtual Water Trade: The Birth and Growth of a New Research Field in Spain
}

\author{
Maite M. Aldaya ${ }^{1, * \mathbb{D}}$, Alberto Garrido ${ }^{2,3}$ and Ramón Llamas ${ }^{3,4}$ \\ 1 Institute for Innovation \& Sustainable Development in the Food Chain (IS-FOOD), \\ Public University of Navarra (UPNA), Jerónimo de Ayanz Centre, Arrosadia Campus, \\ 31006 Pamplona, Spain \\ 2 Research Center for the Management of Environmental and Agricultural Risks (CEIGRAM), \\ Universidad Politécnica de Madrid, Complutense Avenue, 28040 Madrid, Spain; alberto.garrido@upm.es \\ 3 Water Observatory, Botín Foundation, Castelló 18C, 28001 Madrid, Spain; mramonllamas@gmail.com \\ 4 Royal Academy of Sciences of Spain, Valverde 22, 28004 Madrid, Spain \\ * Correspondence: maite.aldaya@unavarra.es
}

Received: 31 August 2020; Accepted: 14 September 2020; Published: 21 September 2020

\begin{abstract}
The growth in the number of studies applying and expanding the concepts of the water footprint and virtual water trade in Spain has generated a wealth of lessons and reflections about the scarcity, allocation, productive use, and management of water from the viewpoint of a semi-arid country. This paper reviews the evolution of this research field in Spain since its introduction in 2005 and reflects on its main contributions and issues of debate. It shows how these concepts can be useful tools for integrated water accounting and raising awareness, when used with certain precautions: (1) Supply-chain thinking, taking into account value chains and the implications of trade, generally ignored in water management, can help to address water scarcity issues and sustainable water use. (2) Green water accounting incorporates land use and soil management, which greatly influences hydrological functioning. (3) The grey water footprint indicator analyzes pollution from an ecosystem point of view and facilitates the understanding of the water quantity and quality relationship. (4) Apparent water productivity analysis, innovatively incorporated into Spanish studies, considers the economic and social aspects associated with water use. However, the decision-making context should be broader, contextualizing and complementing water information with other indicators.
\end{abstract}

Keywords: water footprint; virtual water trade; apparent water productivity; supply chain; water scarcity; water management; Spain

\section{Introduction}

Spain is a semi-arid, water-scarce country, with unequal water distribution and relatively higher water abundance in the north than in the south. For decades, its economy has relied on the tourism and agricultural sectors, both very demanding in terms of water resources. In 2018, the agricultural sector accounted for approximately $59 \%$ of the total water use and $3 \%$ of the country's gross domestic product (GDP) and employed $4 \%$ of the economically active population [1]. By contrast, the industrial sector represented $10 \%$ of the total water use, $16 \%$ of the GDP, and $13 \%$ of the economically active population, while the urban water supply amounted to $31 \%$ of the total water use [1]. As shown by Duarte et al. [2], Cazcarro et al. [3], and Garrido and Llamas [4], historically, Spain has constantly struggled to harness its water resources and to maximize its economic and social returns.

The Spanish economy eventually started to become disentangled from the expansion of water use in the early 1990s. Between 1996 and 2007, Spain's GDP more than doubled in real terms and the share of the agricultural sector diminished progressively to a meager $4 \%$, while total water use 
remained stable at 32 billion $\mathrm{m}^{3}$ per year [5]. However, the scarcity of water is felt sharply during drought periods, which occur every 5-6 years [6].

Hitherto, little or no attention has been given to the quality of freshwater or to the health of riverine ecosystems, which are still a challenge in terms of the implementation of the European Water Framework Directive (2000/60/EC; WFD) and the Nitrates Directive (91/676/EC) concerning the protection of water bodies against pollution caused by nitrates from agricultural sources.

It should not be surprising that the concepts of the water footprint (WF) and virtual water trade (VWT) caught the attention of scholars in Spain not long after their initial development [7-9]. The first publication to introduce these concepts in Spain was by Llamas in 2005 [10], who highlighted their usefulness in alleviating water scarcity, particularly in arid and semi-arid regions.

Spain was the first country to include WF analysis into governmental policy-making. In 2008, the Spanish government adopted a regulation that requires incorporating WF and VWT analyses within river basin plans in the context of the WFD [11].

Spanish WF studies are characterized by their detailed spatial dimensions-their local, provincial, and regional case study-based coverage-from year to year. They have refined the methodology of earlier studies $[12,13]$, including a number of modifications to adapt the general approach to the Spanish context, including green and blue water estimation separately for rainfed and irrigated crops [5], and a grey WF detailed analysis differentiating between surface and groundwater bodies [14,15]. A significant innovation of these Spanish studies has been to emphasize the challenge of considering economic aspects and the inclusion of apparent water productivity analysis [5].

This article summarizes the evolution of WF and VWT assessments in Spain since their first reference [10], with a specific focus on the social and policy dimensions. It aims to show how these concepts have changed the perception of water scarcity and allocation in Spain, improved the understanding of the linkage between human pressures and policies and the impact on water, and contributed to communicating the importance of water resources in Spaniards' consumption habits and the economy. Finally, challenges and opportunities for the incorporation of the WF and VWT into Spanish river basin management plans are discussed, and innovations for water planning, industries, and consumers are highlighted.

\section{Materials and Methods}

The present review covered 145 Spanish empirical studies, of which only $28 \%$ of the "water footprint" studies were published more than five years ago (Figure 1). The literature review was performed using the Web of Science research tool in August 2020 with the search terms "water footprint", "virtual water", and "Spain" (Figure 1). The search was limited to publications in English between the years 2000 and 2020.

In the following sections, we briefly reviewed this literature from historical and sectoral perspectives. 


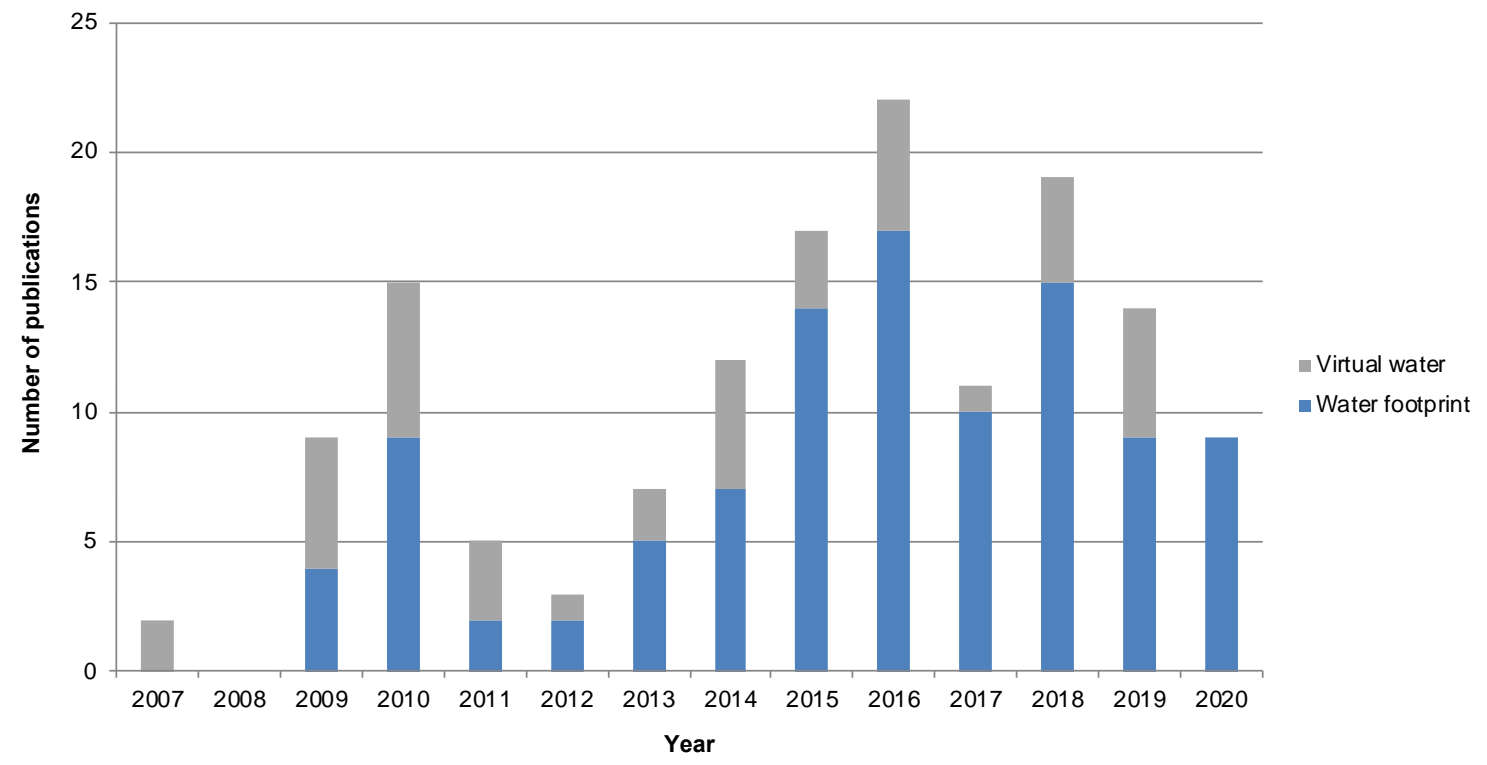

Figure 1. Number of publications per year using the terms "water footprint" and "Spain," as well as "virtual water" and "Spain" during the period 2000-2020 according to the Web of Science (accessed 10 August 2020).

\section{Historic Developments}

\subsection{Roots of WF and VWT Assessments in Spain}

The concept of VWT, referring to the volume of water used to produce traded goods, was introduced by Allan in the 1990s [7,8,16]. Allan's work focused on mitigating water scarcity in Middle Eastern dry areas by "importing" water, virtually embodied in food commodities, instead of producing food domestically.

The WF concept, telling the other side of the story, positing that there is a "water footprint" in exporting countries that may deplete local water resources, was first introduced by Hoekstra $[9,17]$. According to Hoekstra et al. [18], the WF is a multidimensional indicator, specified geographically and temporally, which comprises of the blue WF (consumption of surface and groundwater resources), green WF (consumption of rainwater insofar as it does not become run-off) [19], and grey WF (volume of freshwater that is required to assimilate the load of pollutants, given natural background concentrations and existing ambient water quality standards) [20]; the last two have a historical engineering focus.

The green and blue WF and VWT concepts were introduced in Spain by Llamas early in 2005 [10]. Llamas' optimistic perspectives pointed at the usefulness of the WF and VWT as tools for improving water management and alleviating water scarcity, particularly in arid and semi-arid countries. According to the author, clear data and tools, including the WF and VWT, could help to improve water mismanagement in Spain, which is due to several reasons, such as the persistence of the food self-sufficiency idea eschewing trade, the still imperfect international trade agreements, agricultural commodity prices and perverse subsidies, and national policies that promote only the expansion of irrigated areas [4,10].

Green and blue WF assessments were rapidly incorporated into Spanish studies [5,21-26], while the grey WF assessment was incorporated later $[14,15,27,28]$. All of these studies were conducted at high spatial and temporal resolution and refined the methodology of previous studies to adapt the global approach to the Spanish context and particularities. The Water Observatory of the Botin Foundation initially led the WF research, which soon after broadened in scope. Spanish research innovatively coupled green and blue WF analyses with apparent water productivity and the economic value of the different sectors in Spain (Section 3.2), pioneered the use of input-output models to trace the importance of water (Section 3.3), proved the VWT as a tool for mitigating water scarcity (Section 3.4), 
developed the first application of the WF at the river basin scale (Section 3.5), pointed at the WF and VWT as valuable tools for more effective integrated water resources management (IWRM; Section 3.6), deepened the understanding of the connections with dietary choices (Section 3.7) and the water-energy nexus (Section 3.8), and made a step forward in differentiating between surface and groundwater in detailed grey WF studies (Section 3.9).

\subsection{Green and Blue WF and the Economic Value of the Different Sectors in Spain}

\subsubsection{Single-Product or Sectoral Evaluations}

A pioneering work in Spain was the evaluation of the WF across the whole of the Spanish agricultural sector [24], which was performed in parallel with a similar study on the entire livestock sector, finding widely different evaluations across animal species [25]. These two works, carried out at the provincial level, differentiating between rainfed and irrigated production and considering dozens of products, later inspired dozens of studies that refined these initial assessments.

Green water use in agriculture and livestock varies from year to year due to unstable precipitation regimes [23], and the VWT mitigates the supply shocks caused by droughts. Meanwhile, a single-product WF revealed wide inconsistencies and differences in figures. Variations in the evaluation of the WF for a single product were found to be significant across production areas and production techniques for olive oil [26], tomato [22,29], cotton [30], and sugar cane [31].

Other authors used the WF analysis in much better and more precise works, also at the sectoral level, for instance, the pork industry, in a study conducted by de Miguel et al. [27]. More recent studies have looked at the WF of processed products such as gazpacho, a typical chilled vegetable soup [32], and various types of hams and sausages [33].

\subsubsection{Evaluations of Economic Water Productivity: Moving from "More Crops per Drop" to "More} Jobs per Drop"

Garrido et al. [5] evaluated the apparent water productivity (a simple ratio between the value of production and the total WF) at the regional and provincial levels. This gave rise to a simple but, until then, ignored fact: A large part of the blue WF in Spain was devoted to low-value crops. It was also found that the evaluation of the number of jobs per drop would help provide evidence of the inefficient allocation of scarce blue water resources in Spain.

Dumont et al. [34] found that for the Guadalquivir basin, the economic productivity fluctuates between less than $0.40 € / \mathrm{m}^{3}$ for the most traditional crops (i.e., cereals, maize, cotton, and rice) to values reaching $2 € / \mathrm{m}^{3}$ for olives and more than $4 € / \mathrm{m}^{3}$ for vegetables. However, the highest economic productivity is tourism (more than $200 € / \mathrm{m}^{3}$ ) and industries such as thermo-solar energy $\left(50 € / \mathrm{m}^{3}\right)$. The reallocation of water could be achieved without social conflict with farmers, since the quantities of blue water required constitute $1-2 \%$ of the current total blue water use.

Similar conclusions were reached by Aldaya et al. [35] (Figure 2) and Pellicer-Martínez and Martínez-Paz $[15,36,37]$ for the Segura basin, a significant hotspot of water scarcity in Europe. 


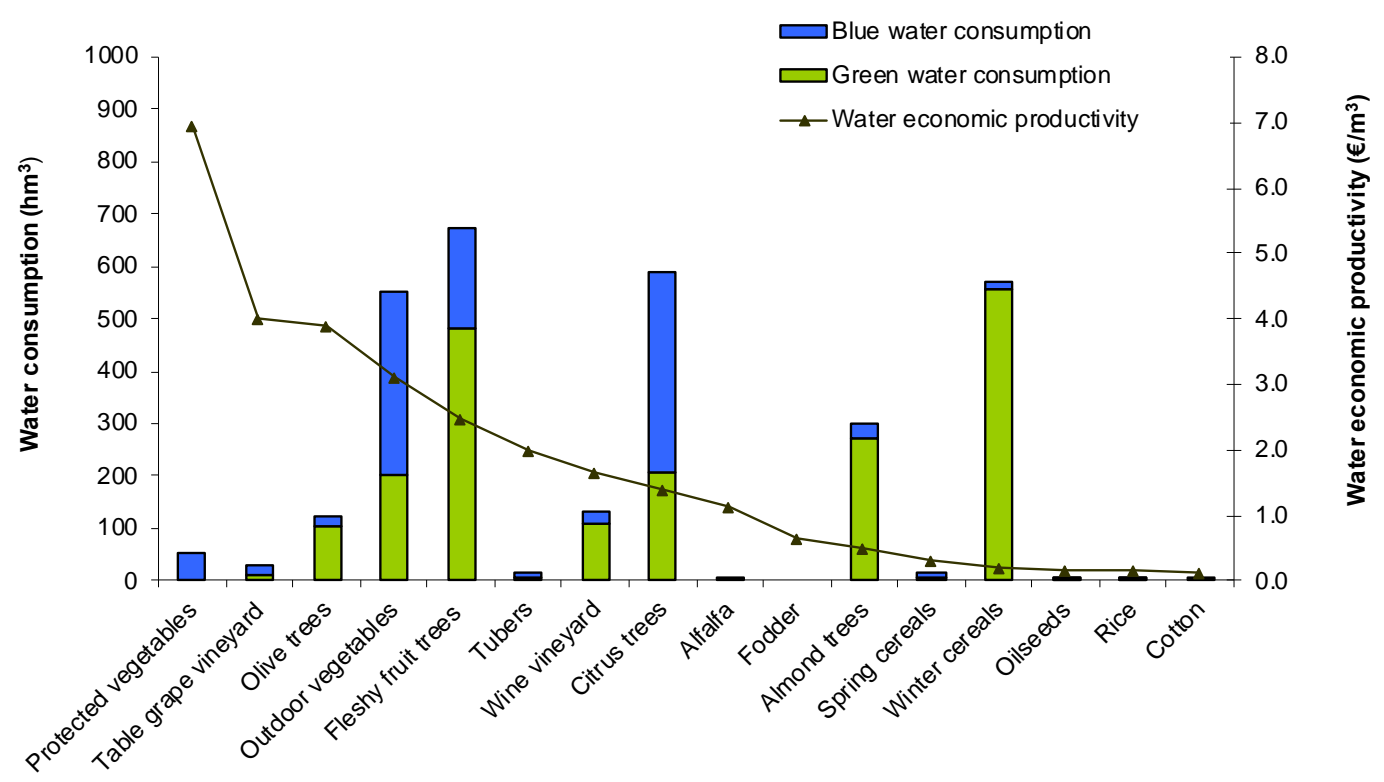

Figure 2. Blue and green water consumption and blue water economic productivity in the Segura basin. Source: Aldaya et al. [35].

\subsection{The Use of Input-Output Models}

In pioneering work, Dietzenbacher and Velázquez [38] applied input-output models to trace the importance of water in the region of Andalusia, obtaining a matrix of intersectoral water relationships, considering 24 economic sectors. Their analyses showed the importance of making a distinction between direct and indirect consumption in Andalusia, a water-scarce region, whose economic structure is strongly dependent on sectors that are high water consumers (e.g., the food and agriculture and tourism sectors).

Cazcarro et al. [39] carried out a regional evaluation, showing an important imbalance between the origin of water resources and the final destination, with significant water pressures in the south, Mediterranean, and some central regions. Madrid and Barcelona are important drivers of water consumption in Spain. The main virtual water exporters are the southern and central agricultural regions: Andalusia, Castile-La Mancha, Castile-Leon, Aragon, and Extremadura, while the main virtual water importers are the industrialized regions of Madrid, Basque country, and the Mediterranean coast.

\subsection{The VWT in Spain: Addressing Water Scarcity Problems}

Perhaps one of the most widely cited and downloaded works is the book of Garrido et al. [5]. This work represented, at its time, a fresh attempt to look at water resources in Spain from new and innovative perspectives. Some of the questions addressed were: What is the VWT and WF of Spain? Are the green and blue water (i.e., surface and groundwater) components different and significant? What are the economic implications for water allocation in Spain in light of these new evaluations? Should we revisit the paradigm of water scarcity in Spain and in most semi-arid countries? What do the economic evaluations of the VWT and WF imply in terms of the practical applications of these concepts?

It was found that Spanish agricultural trade grew in real terms between 1997 and 2006, both in imports and exports, overcoming water scarcity limitations with the VWT, with net water imports being predominant and even widening the gap during the 1996-2006 period of study. The agricultural economy showed a clear dependence on virtual water imports in the form of cereals and animal feed, which has continued to grow in the last 25 years. The book's conclusions redefined two hitherto important aspects for assessing water scarcity in Spain. First, it showed how agricultural trade mitigated the effects of drought cycles, indicating that booming industries such as the pork and tourist 
sectors could rely on the VWT indirectly. Second, the analyses revealed the large amounts of scarce blue water devoted to low-value crops, a finding that would be repeatedly shown in more recent studies.

\subsection{River Basin Studies: Considering the Global and Territorial Dimensions in Water Planning}

The first river basin-specific WF studies emerged in Spain in 2008, with pioneering examples such as the cases of the Guadiana river basin [21,40], the Guadalquivir river basin [34], the Duero river basin [28], the Genil river basin [41], the Turia river Basin [42], and the Segura river basin [35-37]. All of these basins are important agricultural regions, where the largest share of water is used in agriculture.

These studies pointed out the usefulness of WF-related concepts, combined with the currently used ones, to improve the understanding of water availability and management, to develop a more complete water balance, and to help advance toward more integrated and sustainable management in water planning when used adequately, considering its particularities.

First, this literature highlights the importance of the generally unaccounted green or soil water, which is a dominant factor in the hydrological cycle. For instance, more than $80 \%$ of the rainfall turns into green water in Southern Spanish semi-arid basins, such as the case of the Guadalquivir and Genil basins [34,41]. Green water can be indirectly managed through land use changes or agricultural management practices. According to Salmoral et al. [41], green water use efficiency under rainfed conditions could be improved with measures such as long-term conservation tillage, mowing of natural vegetation, or diversification of crop rotation. In the case of the Segura basin, small changes in land use could increase natural water resources when considering surface run-off and infiltration [36]. Green water scarcity was analyzed in two Spanish studies [36,41] in order to explain and include the limits associated with green water use. In both cases, the green WF was mapped and compared to maximum sustainable levels, that is, to the total green water availability considering the green water requirements to support biodiversity. These concepts in the analyzed basins seem to be essential for adopting more integrated land and water resource management and land use planning [41].

Second, in today's globalized world, these studies pointed at the usually ignored VWT analysis as a useful input for better understanding the activities of basins and for shedding an optimistic light on mitigating water scarcity $[21,35,40]$. For instance, in the southeastern semi-arid Segura river basin, virtual water imports are four times higher than the disputed water transfer rate to the Segura basin from other river basins [35]. The incorporation of the notion of VWT in water planning, through the exchange of goods or crop limitation actions, could help to reduce the pressure on local water resources and to mitigate water scarcity and drought periods at the basin level [21,35]. This reduction in the demand on local water resources could free up water that can be used to provide ecological services and other more profitable uses. In turn, this trade could ideally add value to the economy of the region. Nevertheless, the potential spill-over effects should be carefully assessed to prevent negative socioeconomic and environmental consequences [35].

Third, from a Mediterranean country perspective, these Spanish studies revealed the relevance of considering the climate fluctuations and temporal variability, as well as the trends of water availability and use, moving beyond the average values commonly considered in WF studies [35]. Some of the Spanish analyses studied the WF in three different hydrological years (i.e., dry, humid, and average) $[21,40,41]$, while others analyzed the evolution of the WF across a long-term period-12 years in the case of the Guadalquivir basin [34].

Fourth, these Spanish studies also emphasized the need for WF studies to consider different water sources, not only conventional water resources (i.e., surface and renewable and non-renewable groundwater), but also external resources (i.e., interbasin transfers) and unconventional water resources (i.e., desalination and water reuse) [35,36], as diversifying water sources is key for coping with water scarcity in semi-arid countries.

Fifth, the studied papers recommended analyzing basin water use and demands in a disaggregated way, beyond an economic sectoral approach. It is particularly important to disaggregate the agricultural sector by crop type, as the agricultural sector is generally the main water user [35]. 
Sixth, the analyzed river basin cases show the relevance of disaggregating WF basin assessments at the sub-basin level, as shown by the cases of Guadiana and Guadalquivir [21,34,40].

Finally, an innovation of these Spanish studies is the combination of the WF with apparent water productivity analyses by subsectors, which is useful for understanding the economic rationale of basin activities [35]. According to the analyzed studies, this can help to achieve an efficient allocation of water and economic resources at the catchment level. Nevertheless, it is recognized that WF assessments provide only a partial overview of the problem, as water is not the only factor of production, and other factors, such as energy, may play a role. Therefore, WF analyses need complementary tools to balance factors such as risk diversification and labor, as well as other socioeconomic, agronomic, and ecological considerations [40].

\subsection{Relation to IWRM}

Several Spanish studies pointed at the WF and VWT as important tools for achieving more effective IWRM, providing complementary information, such as the green and blue WF, VWT, and grey WF, to traditional water accounting indicators $[5,10,15,41,43]$.

The concept of IWRM is a process that promotes the coordinated development and management of water, land, and related resources in order to maximize the resultant economic and social welfare in an equitable manner without compromising of the sustainability of vital ecosystems according to the Global Water Partnership (GWP). However, implementing it in practice is not a simple task [43].

Interdisciplinary research on the political-ecology of water in Spain shows how water politics, economics, culture, and engineering have created tensions and conflicts that have shaped Spanish society over the years. The current water geography and ecology of Spain is the product of the socioecological interaction throughout the centuries. Nevertheless, all these interlinkages have remained largely unexplored [44].

First, the application of the WF to Spanish conditions shows that water policy is fundamentally conditioned by agricultural policy [10]. This is particularly true in Spain, where agricultural water use, including green and blue water crop consumption and livestock water use, represents approximately $85 \%$ of the nation's total water consumption [5]. In certain Spanish regions, such as the Upper Guadiana basin, conflicts between agriculture and the conservation of rivers and groundwater-dependent wetlands are common [21]. From this, a clear corollary seems to be derived: Spanish water policy should not be planned and practically decided almost exclusively by the General Directorate of Water of the Ministry of the Environment [10]. A coordinated approach is required with respect to both agricultural policies and water legislation, as well as future land and WF studies, in order to evaluate the implications of modifications in actual land use and agricultural management practices for local water systems in terms of quantity and quality [41]. The results of Salmoral et al. [41] revealed the existing opportunities for adopting integrated land and water resource management to reallocate water to productive uses, as well as to mitigate water degradation caused by soil erosion.

Second, given the role of agriculture as the main water consumer in Spain, the food trade may provide a valuable means to balance the irregular distribution of water across regions [43]. The VWT is an element that can mitigate water crises in Spain $[5,10]$. However, in addition to improving calculation methods and data collection, it seems necessary to better understand its economic, social, geopolitical, and ecological implications (ibid.).

Third, the overall water figures tend to overlook the problem of diffuse pollution, and this is perhaps one of the greatest challenges of our century [43]. In this context, the grey WF can be used as an additional indicator of water pollution, able to account for diffuse pollution, in the water planning processes within the framework of IWRM [15].

Finally, in the case of urban environments, the widening urban water footprint increasingly lead to water conflicts. For instance, there are conflicts between ecological conservation and urban water needs, and between agricultural and urban water use during dry periods in Seville, Andalusia [45]. Producing a sustainable urban environment requires a comprehensive approach that integrates water 
supply with ecological considerations, socioeconomic processes, health and sanitation policy, and urban planning and governance systems. The fragmentation of policy domains makes achieving this goal more difficult [45].

\subsection{The WF of Dietary Choices}

A number of studies have evaluated the WF of various diets and consumption habits. Blas et al. [46] evaluated the WF of two recommended diets, namely, the Mediterranean and American diets, in order to assess the Mediterranean diet as a sustainable dietary pattern, and to evaluate the water savings of possible dietary shifts in Spain and the U.S. The results showed that the American diet has a higher total WF in comparison with the Mediterranean diet, regardless of where the products are produced. In the U.S., a shift to a Mediterranean diet would decrease the consumptive WF (green and blue) by $29 \%$ (1252 L/capita/day). Meanwhile, a shift toward an American diet in Spain would increase the consumptive WF also by $29 \%$ (1277 L/capita/day). The largest share of the WF of both diets is linked to green water, which implies that the largest impact of dietary shifts is also linked to land use. Grey water in the U.S. is $67 \%$ higher than in Spain.

Blas et al. [47] also assessed the water-related implications of food consumption and waste among Spanish households to discern possible policy recommendations. The results showed that the estimated total WF of food waste at the household level was $131 \mathrm{~L} /$ capita/day (of which $97 \mathrm{~L} /$ capita/day were related to green and $19 \mathrm{~L} /$ capita/day to blue WFs), equivalent to $4 \%$ of the total WF of current consumption.

Finally, Blas et al. [48] assessed and compared the nutritional and water implications of the current food consumption of Spanish households with the recommended Mediterranean diet. They compared their WFs, and developed a new methodological approach to assess nutritional water productivity (i.e., the nutritional value per unit of water embedded). Due to the high water content embedded in animal products, a shift toward a Mediterranean diet would result in an approximate reduction of $753 \mathrm{~L} /$ capita/day in consumptive water (of which 34 are related to the blue WF).

Esteve-Llorens et al. [49] compared three omnivorous diets recommended in Spain due to their health benefits, namely, the Mediterranean diet (MD), the Southern European Atlantic diet (SEAD), and the Spanish dietary guidelines (NAOS). Using the standard life cycle assessment (LCA) and WF methods together with current Spanish food price data, they showed that the dietary energy recommendation of the SEAD is greater than that of the MD and the NAOS (11\% and $15 \%$, respectively), and the SEAD also has a higher animal source food content than the other two diets. The SEAD has a higher WF in comparison to the MD $(+23 \%)$ and the NAOS $(+9 \%)$.

Batlle-Bayer et al. [50], using LCA, found that the adoption of a National Diet Guidelines-based diet can potentially reduce environmental impacts (i.e., greenhouse gas emissions, blue WF, and land use) by between $15 \%$ and $60 \%$ of current regional eating patterns.

\subsection{The Water-Energy Nexus}

One of the most cited papers published in the field of the water-energy nexus is that of Hardy et al. [51]. This paper performed a two-way evaluation, i.e., energy for water and water for energy. It considered all energy generation sources, as well as consumptive and non-consumptive uses, including evaporation rates from reservoirs.

This paper identified the remarkable cooling needs of nuclear, carbon, and gas energy generation, as well as the restrictions that this kind of energy service posed on water management in the largest Iberian rivers of Spain. Nuclear water demands were later re-evaluated by Sesma and Rubio [52], offering a more precise geographical and temporal evaluation.

Hardy et al. [51] also found that all considered scenarios for biofuel production require a large percentage of available green and blue water resources, offering a perspective unknown until then. Finally, they showed the increasing energy requirements of the large transformation of the irrigation systems in Spain, covering $40 \%$ of all irrigated areas and making drip irrigation the principal irrigation technique. After Hardy et al. [51], Willaarts et al. [53] found that the overshooting of energy consumption 
in the irrigation sector in Spain receded because of the increased energy cost represented by irrigators, but the reduction in agricultural water consumption stabilized.

Sesma-Martín and Rubio-Varas [52,54] evaluated the WF of the eight nuclear plants in operation in Spain, finding median annual values ranging from 1.02 to $2.67 \mathrm{~m}^{3} / \mathrm{MWh}$ for the oldest plant. Sesma-Martín [55] analyzed the evolution of the cooling water needs of thermal power plants in the Ebro River basin, the largest contributor to the Spanish electricity grid, over the period 1969-2015, including coal, a natural gas combined cycle, and nuclear plants. He found WFs of similar values, ranging from $0.57 \mathrm{~m}^{3} / \mathrm{MWh}$ for the natural gas combined cycle to $2.60 \mathrm{~m}^{3} / \mathrm{MWh}$ for coal.

\subsection{Understanding and Quantifying the Pressure That Nitrogen Pollution from Different Sectors and Crops Poses on Freshwater}

Most of the grey WF studies in Spain focus on the nitrogen-related grey WF $[14,15,27,28,56]$, except for that of Martinez-Alcala et al. [57], who concentrated on the pharmaceutical grey WF.

Spanish researchers have advanced the nitrogen-related grey WF methodology. Pellicer-Martínez and Martínez-Paz [15] developed an accounting method in the Segura basin that differentiated between surface and groundwater grey WFs. Later, Aldaya et al. [14] used the grey WF and water pollution level (WPL) indicators, based on a soil nitrogen balance approach to differentiate between surface and groundwater in order to better understand and quantify the pressure that nitrogen fertilization places on freshwater. This study showed that both the grey WF and WPL indicators could help improve the understanding of the relationship between human pressures and policies and the nitrogen impact on water. For the first time, they compared the results of these indicators with actual nitrogen concentration data in surface and groundwater bodies, showing, in both cases, a significant positive correlation. This means that theoretical WPL results might be valuable for anticipating and identifying nitrate pollution in surface and groundwater bodies, particularly where no actual data are available. However, they also recommend field verifications for the factors that influence N-related processes, such as natural attenuation.

The study by Martinez-Alcala et al. [57], for the first time, analyzed the grey WF applied to the pharmaceutical case. This study focused on the southeastern region of Murcia, where wastewater treatment plants treat $99 \%$ of the wastewater and the treated wastewater is commonly reused in irrigation. This work accounted for the grey WF of four of the most common pharmaceutical compounds (i.e., carbamazepine, diclofenac, ketoprofen, and naproxen), as well as the main conventional pollutants (i.e., nitrates, phosphates, and organic matter), showing that the grey WF is not only due to conventional pollutants but also pharmaceutical pollutants can become critical. The results revealed that the grey WF of pharmaceutical pollutants could be used to provide a first approximation of the dilution that should be applied to the treated wastewater discharges when they are reused for another economic activity that imposes quality restrictions. For the case of agriculture in the Murcia region, the dilution required is 2 parts fresh water to 1 part treated wastewater, taking into account the pollution thresholds. However, the reuse of treated wastewater is controversial, considering the pharmaceutical contaminants and their possible consequences in the food chain [57].

\section{Discussion}

\subsection{Policy Relevance at the Basin Scale}

Since the birth of the WF and VWT fields, there has been a discussion about their policy implications and practical application. Interesting reflections at the river basin level have arisen from the Spanish case, due to a combination of extensive academic research since the year 2005 [10] and the early policy incorporation of these concepts. 


\subsubsection{Application to Spanish Water Planning and Challenges}

In 2008, the Spanish government adopted a legal requirement, unique across the world, incorporating the WF assessment as part of the river basin management plans that the government must implement in the transposition of the European Water Framework Directive (2000/60/EC). This requirement indicates that in the economic characterization of water uses, a WF assessment of the different socioeconomic sectors should be conducted, understood as the total sum of the water used of internal origin and the net balance of imported and exported water in each river basin [11]. This requirement has served to incorporate the WF into the characterization studies of such plans, and yet, WF assessments have been rendered useless and do not inform the resource allocation process or water planning criteria. There are reasons for this lack of impact.

The latest river basin management plans (2015-2021), using input-output tables, include the green, blue, and grey WF accounts without generally considering the socioeconomic and environmental impacts and with a very limited extension (Table 1) [58]. These analyses use their own terminology and methodology [59] that differ from internationally recognized methods, such as the Water Footprint Assessment Manual [18], which is a limitation in terms of completeness and comparability. Generally, WF and VWT assessments are developed at the river basin level, without considering the sub-basin particularities, except for the Miño-Sil basin that offers WF data per municipality. Furthermore, most of the studies include aggregate WF data, without disaggregation within sectors. The only exception is the Ebro river basin, which offers the agricultural sector disaggregated by crops. However, the Ebro results show the total WF, without differentiating between the green and blue components. This could be important in the case of agriculture, which is the main freshwater-consuming sector in Spain [5]. Apparent water productivity analysis, proposed by Spanish researchers [5,34,35], has not been incorporated in the river basin plans, except for that of the Guadiana river basin. The only socioeconomic variables considered are the GDP per capita in the Cantábrico-Oriental, Guadiana, and Segura basins, the household income per capita in the Cantábrico-Oriental and Guadiana basins, and the gross value added in the case of the Guadiana basin. Only two basins, namely, the Duero and Guadiana river basins, compared the WFs with the maximum sustainable levels. In the case of the blue $\mathrm{WF}$, an environmental reserve of $10 \%$ was considered in both cases. However, in the case of the green water limits in the Duero basin, the total evapotranspiration was used, without setting aside a green water flow to support natural terrestrial ecosystems. In terms of data, international trade data are only available at the regional, national, or provincial level. Generally, these administrative boundaries do not match the river basin ones, and adjustments and simplifications are needed. Furthermore, inter-regional trade data are not easily available, as only some autonomous communities provide these data. Finally, a WF assessment is a partial analysis and should always be combined with other indicators into river basin planning. 
Table 1. Water footprint (WF) in Spanish river basin plans (2015-2021). Source: MITECO [58].

\begin{tabular}{|c|c|c|c|c|c|c|}
\hline \multicolumn{2}{|c|}{$\begin{array}{l}\text { River Basin Management Plans } \\
\text { 2015-2021 }\end{array}$} & WF Included & $\begin{array}{l}\text { Disaggregation: } \\
\text { Within Sectors }\end{array}$ & $\begin{array}{l}\text { Disaggregation: } \\
\text { Green, Blue, } \\
\text { Grey Water }\end{array}$ & $\begin{array}{c}\text { Other } \\
\text { Socio-Economic } \\
\text { Variables }\end{array}$ & $\begin{array}{c}\text { Comparison with Maximum } \\
\text { Sustainable Levels: Green, } \\
\text { Blue Water }\end{array}$ \\
\hline \multirow{10}{*}{ 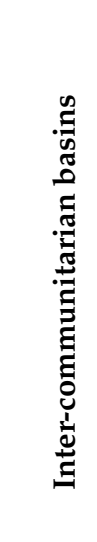 } & Cantábrico-Occidental & $\checkmark$ & & $\checkmark \checkmark$ & $\checkmark$ & \\
\hline & Cantábrico Oriental & $\checkmark$ & & $\checkmark \checkmark$ & & \\
\hline & Duero & $\checkmark$ & & 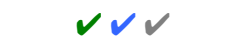 & & $\checkmark v$ \\
\hline & Ebro & $\checkmark$ & $\checkmark$ & $\checkmark v$ & & \\
\hline & Guadalquivir & $\checkmark$ & & $\checkmark v$ & & \\
\hline & Guadiana & $\checkmark$ & & $\checkmark v$ & $\checkmark$ & $\checkmark$ \\
\hline & Júcar & $\boldsymbol{V}$ & & $\checkmark v$ & & \\
\hline & Miño-Sil & $\checkmark$ & & & & \\
\hline & Segura & $\checkmark$ & & $\checkmark v$ & $\checkmark$ & \\
\hline & Tajo & $\checkmark$ & & $\checkmark v$ & & \\
\hline \multirow{7}{*}{ 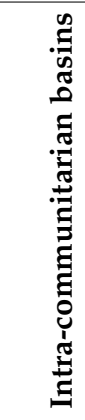 } & Cataluña & $\checkmark$ & & & & \\
\hline & Galicia-Costa & & & & & \\
\hline & Guadalete \& Barbate & & & & & \\
\hline & Islas Baleares & & & & & \\
\hline & Islas Canarias & & & & & \\
\hline & $\begin{array}{l}\text { Mediterráneas } \\
\text { Andaluzas }\end{array}$ & $\checkmark$ & & $\checkmark v$ & & \\
\hline & Tinto, Odiel \& Piedras & & & & & \\
\hline
\end{tabular}




\subsubsection{Innovations for Water Planning}

Information about WF and VWT assessments offers valuable input for different steps of the planning process.

1. Improvement in economic characterization considering virtual water flows:

Virtual water import and export analysis is related to macroeconomic concepts, such as the GDP and jobs, and can provide useful information from an economic planning viewpoint. Additionally, from a water planning perspective, it can be useful to understand the drivers of the pressures of economic activities on water resources. The VWT can alleviate or exacerbate water droughts by the import or export of water embedded in traded products [5,23,60].

2. Criteria to establish the priority of uses:

A green, blue, and grey WF assessment, considering the different water availabilities throughout the year, can point at the water uses that result in lower water consumption, in lower pressure on environmental flows, or in the maintenance or improvement of water quality.

3. Criteria for resource allocation:

During the last 40 years, the frequent political and social conflicts related to water have typically been related to interbasin transfers. This issue is closely linked to the allocations and reserves of resources for current and future uses and demands, including environmental flows, and has been the main element of conflict in river basin management plans, especially in those river basins with fewer available resources in relation to demands.

WF assessments, when coupled with apparent water productivity analyses at the sub-basin level, can integrate the economic and social dimensions of water allocation and might be valuable for increasing its social and economic value, as shown by many Spanish studies [5,34,35]. However, the social dimension is not generally taken into account.

The grey WF can also be a criterion in the decision-making process, as it permits assessment of the water pollution of different alternatives of land planning and water allocation, going beyond strict quantitative hydrological analyses and considerations. It can also be a tool for the ex-ante assessment of the effectiveness of pollution monitoring programs [15].

4. Criteria to guide cost recovery decisions:

WF assessments and their accompanying apparent water productivity can also inform policy decisions about water pricing and cost recovery rates. This, jointly with allocation decisions (point 3 above), supports flexible management and avoids the difficulties associated with using water rates as an allocation mechanism, of which there are many examples around the world.

5. Assessment of the pressures through the grey WF:

The grey WF and the related WPL indicators are able to roughly quantify the dimension and severity of the pressure from different sectors on water bodies in a disaggregated manner and to improve the understanding of the relationship between these pressures and the impact on water bodies. They could even be useful for coarsely predicting and anticipating $\mathrm{N}$ pollution hotspots, where water quality is degraded due to nitrogen pollution from diffuse sources. In order to fine-tune these approaches, they should be combined with field information on attenuation factors [14].

Additionally, the grey WF allows the assessment of the impacts of different pollutants located in different geographical areas and can also be used to compare the impact of pollution with other types of impacts, such as water abstraction from aquifers [15]. This indicator can also point at unsustainable pollution levels. For instance, the Segura river basin's grey WF is greater than its renewable water resources, making it unsustainable in the short and medium term (ibid.).

Although the foundations of the grey WF formulation are well developed, the existing methodologies for calculating the grey WF are still in development. A few articles coauthored by Spanish researchers proposed refinements in the methodology for the application of the grey WF at the river basin level, employing a soil nitrogen balance approach and differentiating between surface and groundwater bodies [14,15]. 


\subsection{Policy Relevance and Innovations for Industries}

In the context of the recent European "Farm to Fork" Strategy, which will enable the transition to sustainable practices by farmers, fishers, and other operators in the food chain [61], the WF concept becomes meaningful.

First, according to the Strategy [61], the European Union's (EU) goals are to reduce the environmental and climate footprint of the EU food system and to strengthen its resilience, as well as to ensure food security in the face of climate change and biodiversity loss and to lead a global transition toward competitive sustainability from farm to fork by tapping into new opportunities. This means, among other things, ensuring that the entire food chain, covering food production, transport, distribution, marketing, and consumption, has a neutral or positive environmental impact, preserving and restoring the freshwater and other resources on which the food system depends; protecting water, as well as land, soil, air, plant, and animal health and welfare; and reversing the loss of biodiversity. In this framework, the green, blue, and grey WF assessments, when combined with the apparent water productivity indicator, are useful inputs for enhancing water use efficiency and for improving the allocation of water resources [5,35].

Second, the grey WF assessment might be useful for achieving the targets of the strategy, which include a reduction in nutrient losses by at least $50 \%$, while ensuring that there is no deterioration in soil fertility [61]. This will reduce the use of fertilizers by at least $20 \%$ by 2030 . As shown by the Spanish research outlined in this article, the assessment of alternative practices or activities and predictions on the effect of human activities on $\mathrm{N}$ water pollution can be inferred from the detailed grey WF models [14].

As consumers are becoming increasingly more aware of the environmental impacts of their consumption habits, companies are seeking ways to reduce them and to communicate their achievements. This is clearly a result and response to the two decades of academic work focused on conducting evaluations of the WF of products.

\subsection{Raising Consumer Awareness and Enhancing the Double Dividend "Health-Environment"}

The WF of single-product and consumption habits has inspired a significant proportion of studies in the Spanish literature domain. The WF evaluations of different diets, and some popular goods such as jeans [30], have caught the attention of the general media, which is a constant means of dissemination surrounding the importance of water in many aspects of human life. The commonly found double dividend of a better, healthy diet and a lower environmental impact has also attracted the attention of the general media, making the concept of WF more understandable to consumers. Lastly, analyses of food waste, which is a top environmental priority in both developed and developing countries, have been easily extended to evaluate water and energy losses caused by this waste [47].

\subsection{The COVID-19 Pandemic's Impact on VWT in Spain}

The COVID-19 pandemic impact on VWT depends on multifaceted and complex aspects and variables. According to a recent study by Hussein and Greco [62], scenarios may move from a new food-protectionism to an increase in food trade, depending on several factors, including labor and price and availability of energy for irrigation in importing and exporting countries.

Spain, together with France, is the largest trader of agricultural goods in the Mediterranean [63]. Overall, it is a net virtual-water importer; importing about 12,800 million $\mathrm{m}^{3}$ more virtual water than it exports [5]. In a business as usual context, the scenario of food protectionism in Spain would increase domestic water demand, which may have negative effects on water bodies, particularly during drought cycles. If the climate change scenario is taken into account, the result would be worse as water availability in the period 2000-2050 is predicted to drop by $8 \%$ [63]. The supply chains of those sectors relying on virtual water imports, such as the tourism or the pork industry, may also be affected. 


\section{Conclusions}

The growing literature of WF in Spain has addressed many aspects related to water use, management, and policy. It covers a wide range of approaches, from single-product, sectoral, regional, basin-wise, and consumption studies to national and international studies. This literature has informed policy and business decisions with increasing influence. Consumers have also become the target of many media reports and news, which rely on this wealth of scientific work. WF evaluations have helped communicate the ubiquitous presence of water in all aspects of people's lives and the economy.

Professors Hoekstra and Allan, jointly and separately, initiated this whole area of the literature, having profoundly impacted the dozens of Spanish scholars and authors of the papers reviewed here. This literature will keep growing, offering new insights and more robust analyses.

We believe two strands of the literature attract most of the attention for academic research. The first is finding ways of refining the grey WF component, putting it in the context of a water body assimilation capacity and validating it locally considering attenuation factors. The grey WF, even if it was initially the one that attracted the most criticism and was the weakest in terms of its capacity to inform environmental policy and business innovation, in contrast to LCA assessments, has an enormous potential for linking and predicting the impact of different human activities on water resources. The second one involves the need to assess WF in the context in which it occurs, that is, relating the WF to its actual impact at the local, regional, and basin levels, overcoming the limitation of scope and entering the realms of the environmental, economic, and social contexts.

Author Contributions: M.M.A. and A.G. wrote the draft and contributed to the finalization of the paper. R.L. contributed with his ideas and knowledge. All authors have read and agreed to the published version of the manuscript.

Funding: This research was carried out with the support of Obra Social La Caixa and the Caja Navarra Foundation (Spain) talent grant.

Acknowledgments: The authors are grateful to the administrative support of the ISFOOD-UPNA, the UPNA and the Water Observatory of the Botín Foundation.

Conflicts of Interest: The authors declare no conflict of interest. The funders had no role in the design of the study; in the collection, analyses, or interpretation of data; in the writing of the manuscript, or in the decision to publish the results.

\section{References}

1. Statistics Water Economic Accounts. Labour Market. National Statistics Institute of Spain. Available online: https://www.ine.es/dyngs/INEbase/listaoperaciones.htm (accessed on 15 July 2020).

2. Duarte, R.; Pinilla, V.; Serrano, A. The water footprint of the Spanish agricultural sector: 1860-2010. Ecol. Econ. 2014, 108, 200-207. [CrossRef]

3. Cazcarro, I.; Duarte, R.; Martín-Retortillo, M.; Pinilla, V.; Serrano, A. How Sustainable is the Increase in the Water Footprint of the Spanish Agricultural Sector? A Provincial Analysis between 1955 and 2005-2010. Sustainability 2015, 7, 5094-5119. [CrossRef]

4. Garrido, A.; Llamas, M.R. Water Policy in Spain; Taylor \& Francis: Leiden, The Netherlands, 2009; pp. 1-234.

5. Garrido, A.; Llamas, M.R.; Varela-Ortega, C.; Novo, P.; Rodriguez-Casado, R.; Aldaya, M.M. Water Footprint and Virtual Water Trade in Spain: Policy Implications; Springer: New York, NY, USA, 2010; pp. 1-153.

6. Tejedor, E.; De Luis, M.; Cuadrat, J.M.; Esper, J.; Saz, M.A. Tree-ring-based drought reconstruction in the Iberian Range (east of Spain) since 1694. Int. J. Biometeorol. 2015, 60, 361-372. [CrossRef] [PubMed]

7. Allan, J.A. 'Virtual water': A long term solution for water short Middle Eastern economies? In Proceedings of the 1997 British Association Festival of Science, Leeds, UK, 9 September 1997.

8. Allan, J. Virtual Water-The Water, Food, and Trade Nexus. Useful Concept or Misleading Metaphor? Water Int. 2003, 28, 106-113. [CrossRef] 
9. Hoekstra, A.Y. Virtual water trade. In Proceedings of the International Expert Meeting on Virtual Water Trade, Delft, The Netherlands, 12-13 December 2002; Value of Water Research Report Series. UNESCO-IHE: Delft, The Netherlands, 2003; Volume 12, pp. 1-248. Available online: www.waterfootprint.org/Reports/ Report12.pdf (accessed on 15 July 2020).

10. Llamas, M.R. Los Colores del Agua, El Agua Virtual y los Conflictos Hídricos. Inaugural speech, academic year 2005-2006. Span. R. Acad. Sci. J. 2005, 99, 369-389.

11. Approval of the Water Planning Instruction. Official State Gazette. Ministry of the Environment and Rural and Marine Affairs; Official State Gazette 229; 22 September 2008. Available online: http://www.boe.es/boe/ dias/2008/09/22/pdfs/A38472-38582.pdf (accessed on 15 July 2020).

12. Chapagain, A.K.; Hoekstra, A.Y. Water Footprints of Nations, Value of Water Research Report Series; UNESCO-IHE: Delft, The Netherlands, 2004; pp. 1-77.

13. Hoekstra, A.Y.; Chapagain, A.K. Globalization of Water: Sharing the Planet's Freshwater Resources; Blackwell Publishing: Oxford, UK, 2008; pp. 1-220.

14. Aldaya, M.M.; Rodriguez, C.I.; Fernandez-Poulussen, A.; Merchán, D.; Beriain, M.J.; Llamas, R. Grey water footprint as an indicator for diffuse nitrogen pollution: The case of Navarra, Spain. Sci. Total. Environ. 2020, 698, 134338. [CrossRef] [PubMed]

15. Pellicer-Martínez, F.; Martínez-Paz, J.M. Grey water footprint assessment at the river basin level: Accounting method and case study in the Segura River Basin, Spain. Ecol. Indic. 2016, 60, 1173-1183. [CrossRef]

16. Allan, J. Virtual water: Tackling the Threat to Our Planet's Most Precious Resource; I.B. Tauris: London, UK, 2011; pp. 1-384.

17. Hoekstra, A.Y.; Mekonnen, M.M. The water footprint of humanity. Proc. Natl. Acad. Sci. USA 2012, 109, 3232-3237. [CrossRef]

18. Hoekstra, A.Y.; Chapagain, A.K.; Aldaya, M.M.; Mekonnen, M.M. The Water Footprint Assessment Manual: Setting the Global Standard; Earthscan: London, UK, 2011; pp. 1-206.

19. Falkenmark, M.; Rockström, J. Balancing Water for Humans and Nature: The New Approach in Ecohydrology; Earthscan: London, UK, 2004; pp. 1-320.

20. Chapagain, A.; Hoekstra, A.Y.; Savenije, H.; Gautam, R. The water footprint of cotton consumption: An assessment of the impact of worldwide consumption of cotton products on the water resources in the cotton producing countries. Ecol. Econ. 2006, 60, 186-203. [CrossRef]

21. Aldaya, M.M.; Llamas, M.R. Water Footprint Analysis for the Guadiana River Basin, Value of Water Research Report Series; UNESCO-IHE: Delft, The Netherlands, 2008; Volume 35, pp. 1-84.

22. Chico, D.; Salmoral, G.; Llamas, M.R.; Garrido, A.; Aldaya, M.M. The Water Footprint and Virtual Water Exports of Spanish Tomatoes. Papeles de Agua Virtual; Fundacion Botin: Santander, Spain, 2010; Volume 8, pp. 1-61.

23. Novo, P.; Garrido, A.; Varela-Ortega, C. Are virtual water "flows" in Spanish grain trade consistent with relative water scarcity? Ecol. Econ. 2009, 68, 1454-1464. [CrossRef]

24. Rodríguez, R.; Garrido, A.; Llamas, M.R. La huella hidrológica de la agricultura española. Ing. Agua 2009, 16, 27-40. [CrossRef]

25. Rodríguez-Casado, R.; Novo, P.; Garrido, A. La Huella Hidrica de la Ganadería Española. Papeles de Agua Virtual; Fundacion Botin: Santander, Spain, 2009; Volume 4, pp. 1-44.

26. Salmoral, G.; Aldaya, M.M.; Chico, D.; Garrido, A.; Llamas, R. The water footprint of olives and olive oil in Spain. Span. J. Agric. Res. 2011, 9, 1089-1104. [CrossRef]

27. De Miguel, Á.; Hoekstra, A.Y.; García-Calvo, E. Sustainability of the water footprint of the Spanish pork industry. Ecol. Indic. 2015, 57, 465-474. [CrossRef]

28. De Miguel, Á.; Kallache, M.; García-Calvo, E.T. The Water Footprint of Agriculture in Duero River Basin. Sustainability 2015, 7, 6759-6780. [CrossRef]

29. Irabien, A.; Darton, R.C. Energy-water-food nexus in the Spanish greenhouse tomato production. Clean Technol. Environ. Policy 2015, 18, 1307-1316. [CrossRef]

30. Chico, D.; Aldaya, M.M.; Garrido, A. A water footprint assessment of a pair of jeans: The influence of agricultural policies on the sustainability of consumer products. J. Clean. Prod. 2013, 57, 238-248. [CrossRef]

31. Chico, D.; Santiago, A.D.; Garrido, A. Increasing efficiency in ethanol production: Water footprint and economic productivity of sugarcane ethanol under nine different water regimes in north-eastern Brazil. Span. J. Agric. Res. 2015, 13, e1203. [CrossRef] 
32. Ibáñez, G.R.; Ruíz, J.M.; Román-Sánchez, I.M.; López, J.C. A corporate water footprint case study: The production of Gazpacho, a chilled vegetable soup. Water Resour. Ind. 2017, 17, 34-42. [CrossRef]

33. Noya, I.; Aldea, X.; Gasol, C.M.; González-García, S.; Amores, M.J.; Colón, J.; Ponsá, S.; Román, I.; Rubio, M.A.; Casas, E.; et al. Carbon and water footprint of pork supply chain in Catalonia: From feed to final products. J. Environ. Manag. 2016, 171, 133-143. [CrossRef]

34. Dumont, A.; Salmoral, G.; Llamas, M. The water footprint of a river basin with a special focus on groundwater: The case of Guadalquivir basin (Spain). Water Resour. Ind. 2013, 1, 60-76. [CrossRef]

35. Aldaya, M.M.; Custodio, E.; Llamas, R.; Fernández, M.F.; García, J.; Ródenas, M.Á. An academic analysis with recommendations for water management and planning at the basin scale: A review of water planning in the Segura River Basin. Sci. Total. Environ. 2019, 662, 755-768. [CrossRef] [PubMed]

36. Pellicer-Martínez, F.; Martínez-Paz, J.M. The Water Footprint as an indicator of environmental sustainability in water use at the river basin level. Sci. Total. Environ. 2016, 571, 561-574. [CrossRef] [PubMed]

37. Pellicer-Martínez, F.; Martínez-Paz, J.M. Probabilistic evaluation of the water footprint of a river basin: Accounting method and case study in the Segura River Basin, Spain. Sci. Total. Environ. 2018, 627, 28-38. [CrossRef] [PubMed]

38. Dietzenbacher, E.; Velázquez, E. Analysing Andalusian Virtual Water Trade in an Input-Output Framework. Reg. Stud. 2007, 41, 185-196. [CrossRef]

39. Cazcarro, I.; Duarte, R.; Sánchez-Chóliz, J. Multiregional Input-Output Model for the Evaluation of Spanish Water Flows. Environ. Sci. Technol. 2013, 47, 12275-12283. [CrossRef]

40. Aldaya, M.M.; Martínez-Santos, P.; Llamas, M.R. Incorporating the Water Footprint and Virtual Water into Policy: Reflections from the Mancha Occidental Region, Spain. Water Resour. Manag. 2009, 24, 941-958. [CrossRef]

41. Salmoral, G.; Willaarts, B.; Garrido, A.; Guse, B. Fostering integrated land and water management approaches: Evaluating the water footprint of a Mediterranean basin under different agricultural land use scenarios. Land Use Policy 2017, 61, 24-39. [CrossRef]

42. Salmoral, G.; Willaarts, B.; Troch, P.A.; Garrido, A. Drivers influencing streamflow changes in the Upper Turia basin, Spain. Sci. Total. Environ. 2015, 503, 258-268. [CrossRef]

43. Martínez-Santos, P.; Aldaya, M.M.; Llamas, R. Integrated Water Resources Management in the 21st Century: Revisiting the Paradigm; Taylor and Francis: London, UK, 2014; pp. 1-311.

44. Swyngedouw, E. Liquid Power: Contested Hydro-Modernities in Twentieth-Century Spain; The MIT Press: Cambridge, MA, USA, 2015; pp. 1-320.

45. Swyngedouw, E.; Kaïka, M.; Castro, E. Urban water: A Political-Ecology Perspective. Built Environ. 2002, 28, 124-137.

46. Blas, A.; Garrido, A.; Willaarts, B. Evaluating the Water Footprint of the Mediterranean and American Diets. Water 2016, 8, 448. [CrossRef]

47. Blas, A.; Garrido, A.; Willaarts, B. Food consumption and waste in Spanish households: Water implications within and beyond national borders. Ecol. Indic. 2018, 89, 290-300. [CrossRef]

48. Blas, A.; Garrido, A.; Unver, O.; Willaarts, B. A comparison of the Mediterranean diet and current food consumption patterns in Spain from a nutritional and water perspective. Sci. Total Environ. 2019, 664, 1020-1029. [CrossRef]

49. Esteve-Llorens, X.; Martín-Gamboa, M.; Iribarren, D.; Moreira, M.T.; Feijoo, G.; González-García, S. Efficiency assessment of diets in the Spanish regions: A multi-criteria cross-cutting approach. J. Clean. Prod. 2020, 242, 118491. [CrossRef]

50. Batlle-Bayer, L.; Bala, A.; Aldaco, R.; Lemaire, E.; Song, G.; Aldaco, R.; Fullana-I-Palmer, P. The Spanish Dietary Guidelines: A potential tool to reduce greenhouse gas emissions of current dietary patterns. J. Clean. Prod. 2019, 213, 588-598. [CrossRef]

51. Hardy, L.; Garrido, A.; Juana, L. Evaluation of Spain's Water-Energy Nexus. Int. J. Water Resour. Dev. 2012, 28, 151-170. [CrossRef]

52. Sesma-Martín, D.; Rubio-Varas, M.D.M. Freshwater for Cooling Needs: A Long-Run Approach to the Nuclear Water Footprint in Spain. Ecol. Econ. 2017, 140, 146-156. [CrossRef]

53. Willaarts, B.; Lechón, Y.; Mayor, B.; De La Rúa, C.; Garrido, A. Cross-sectoral implications of the implementation of irrigation water use efficiency policies in Spain: A nexus footprint approach. Ecol. Indic. 2020, 109, 105795. [CrossRef] 
54. Sesma-Martín, D.; Rubio-Varas, M.D.M. The weak data on the water-energy nexus in Spain. Hydrol. Res. 2019, 21, 382-393. [CrossRef]

55. Sesma-Martín, D. The River's Light: Water Needs for Thermoelectric Power Generation in the Ebro River Basin, 1969-2015. Water 2019, 11, 441. [CrossRef]

56. Galán-Martín, Á.; Vaskan, P.; Antón, A.; Esteller, L.J.; Guillén-Gosálbez, G. Multi-objective optimization of rainfed and irrigated agricultural areas considering production and environmental criteria: A case study of wheat production in Spain. J. Clean. Prod. 2017, 140, 816-830. [CrossRef]

57. Martínez-Alcalá, I.; Pellicer-Martínez, F.; Fernandez-Lopez, C. Pharmaceutical grey water footprint: Accounting, influence of wastewater treatment plants and implications of the reuse. Water Res. 2018, 135, 278-287. [CrossRef] [PubMed]

58. Spanish River Basin Management Plans (2015-2021). Spanish Ministry for the Ecological Transition and the Demographic Challenge. Available online: https://www.miteco.gob.es/ca/agua/temas/planificacionhidrologica/planificacion-hidrologica/planes-cuenca/default.aspx (accessed on 15 August 2020).

59. Esteban Moratilla, F.; Molina Moreno, M.; Fernández Barrena, M. La Huella Hídrica de España; Spanish Ministry for Environment; Marine and Rural Affairs: Madrid, Spain, 2011; pp. 1-177.

60. Aldaya, M.M.; Allan, J.; Hoekstra, A.Y. Strategic importance of green water in international crop trade. Ecol. Econ. 2010, 69, 887-894. [CrossRef]

61. Mowlds, S. The EU's farm to fork strategy: Missing links for transformation. Acta Innov. 2020, 17-32. [CrossRef]

62. Hussein, H.; Greco, F. How will the COVID-19 pandemic impact food security and virtual water "trade"? Future Food J. Food Agric. Soc. 2020, 8, 1-2.

63. Antonelli, M.; Greco, F. The Water We Eat: Combining Virtual Water and Water Footprints; Springer: Cham, Switzerland, 2015; pp. 1-256.

(C) 2020 by the authors. Licensee MDPI, Basel, Switzerland. This article is an open access article distributed under the terms and conditions of the Creative Commons Attribution (CC BY) license (http://creativecommons.org/licenses/by/4.0/). 